\title{
Lewinella agarilytica sp. nov., a novel marine bacterium of the phylum Bacteroidetes, isolated from beach sediment
}

\author{
Soon Dong Lee
}

Correspondence

Soon Dong Lee

sdlee@cheju.ac.kr

\author{
Department of Science Education, Cheju National University, Jeju 690-756, Republic of Korea
}

The genus Lewinella was proposed by Sly et al. (1998) to encompass the marine species of the genus Herpetosiphon (Holt \& Lewin, 1968). The genus currently contains three species, Lewinella cohaerens, Lewinella persica and Lewinella nigricans, all of which were isolated from marine environments, including beach sand and brown mud. Despite having similar morphological characteristics (Holt, 1989), the genera Lewinella and Herpetosiphon were found to belong to different phylogenetic lineages, according to data from 16S rRNA gene sequencing studies (Sly et al., 1998). The genus Herpetosiphon currently contains the thermotolerant freshwater species Herpetosiphon aurantiacus (Holt \& Lewin, 1968) and Herpetosiphon geysericola (Lewin, 1970). This genus is now recognized as belonging to the phylum Cloroflexi (Garrity \& Holt, 2001). On the other hand, the genus Lewinella, together with the genera Haliscomenobacter (van Veen et al., 1973) and Saprospira

The GenBank/EMBL/DDBJ accession numbers for the $16 \mathrm{~S}$ rRNA gene sequences of strain SST-19 ${ }^{\top}$, Lewinella cohaerens ATCC $23123^{\top}$, Lewinella nigricans ATCC $23147^{\top}$ and Lewinella persica ATCC $23167^{\top}$ are AM286229, AM295254, AM295255 and AM295256, respectively.

Cellular fatty acid compositions of strain SST-19 ${ }^{\top}$ and the type strains of recognized species of the genus Lewinella are available as a supplementary table with the online version of this paper.
(Gross, 1911), belongs to the phylum Bacteroidetes within the class Sphingobacteria (Garrity \& Holt, 2001) and forms a distinct clade referred to as the family 'Saprospiraceae'. The aim of this paper was to describe the isolation and identification of a Gram-negative, heterotrophic, gliding bacterium designated strain SST-19 ${ }^{\mathrm{T}}$, and to propose that it represents a novel species of the genus Lewinella.

Strain SST- $19^{\mathrm{T}}$ was isolated from a sediment sample collected at Samyang Beach on the coast of Jeju, Republic of Korea. A sediment sample was taken at a depth of $30 \mathrm{~cm}$ below the surface and was suspended in sterile distilled water. The procedure and medium used for the isolation of bacteria were as described in previous studies (Lee, 2006a, $\mathrm{b}, \mathrm{c})$. The isolate was maintained, at -20 and $-80{ }^{\circ} \mathrm{C}$, as a glycerol solution supplemented with $60 \%(\mathrm{v} / \mathrm{v})$ sterilized natural seawater and $20 \%(\mathrm{v} / \mathrm{v})$ distilled water. For the phenotypic and phylogenetic comparisons, the type strains of the three recognized Lewinella species, L. cohaerens ATCC $23123^{\mathrm{T}}, L$. nigricans ATCC $23147^{\mathrm{T}}$ and L. persica ATCC $23167^{\mathrm{T}}$ (all of which were purchased from the American Type Culture Collection) were grown on marine agar (MA; Difco) at $30{ }^{\circ} \mathrm{C}$.

Extraction of chromosomal DNA and amplification and sequencing of the 16S rRNA gene were performed as 
described previously (Lee, 2007). An almost-complete $16 \mathrm{~S}$ rRNA gene sequence $(1415 \mathrm{nt})$ for strain $\mathrm{SST}-19^{\mathrm{T}}$ was determined in this study. A preliminary BLAST search revealed that the organism belonged to the class Sphingobacteria within the phylum Bacteroidetes (Garrity \& Holt, 2001) and was related to members of the genus Lewinella. To check the accuracy of the sequence, the type strains of the three recognized species of the genus Lewinella were also subjected to 16S rRNA gene sequencing and then to a preliminary BLAST search. Each of the sequences of the type strains of the three species of the genus Lewinella determined in this study (deposited at GenBank/EMBL/ DDBJ) showed a match with its own previously published sequence (Sly et al., 1998), but a striking difference was observed between each pair of sequences. The levels of sequence dissimilarity were as follows: L. cohaerens, $6.1 \%$ (86 out of $1400 \mathrm{nt}$ ), L. nigricans, $5.5 \%$ (80 out of $1403 \mathrm{nt}$ ) and L. persica, $2.8 \%$ (40 out of $1414 \mathrm{nt}$ ). Most of these differences were found between positions 92 and 242 (nucleotide numbering according to Escherichia coli positions; Brosius et al., 1978) in the sequences of $L$. cohaerens, between positions 92 and 193 in those of L. nigricans and between positions 326 and 484 in those of L. persica.

The 16S rRNA gene sequence of strain SST $-19^{\mathrm{T}}$ was aligned with those of related genera of the class Sphingobacteria by using the CLUSTAL_X program (Thompson et al., 1997) and then manually optimized according to the secondary structure of the E. coli $16 \mathrm{~S}$ rRNA gene. Evolutionary distances were calculated by using the model of Jukes \& Cantor (1969) and a phylogenetic tree was constructed using the neighbour-joining method (Saitou \& Nei, 1987). The topology of the tree was evaluated by bootstrap analysis (Felsenstein, 1985) of 1000 replicates. A neighbour-joining tree (Fig. 1) based on an analysis of the 16S rRNA gene sequences showed that strain SST $-19^{\mathrm{T}}$ was related to members of genus Lewinella within the family 'Saprospiraceae' and formed a consistent cluster with $L$.

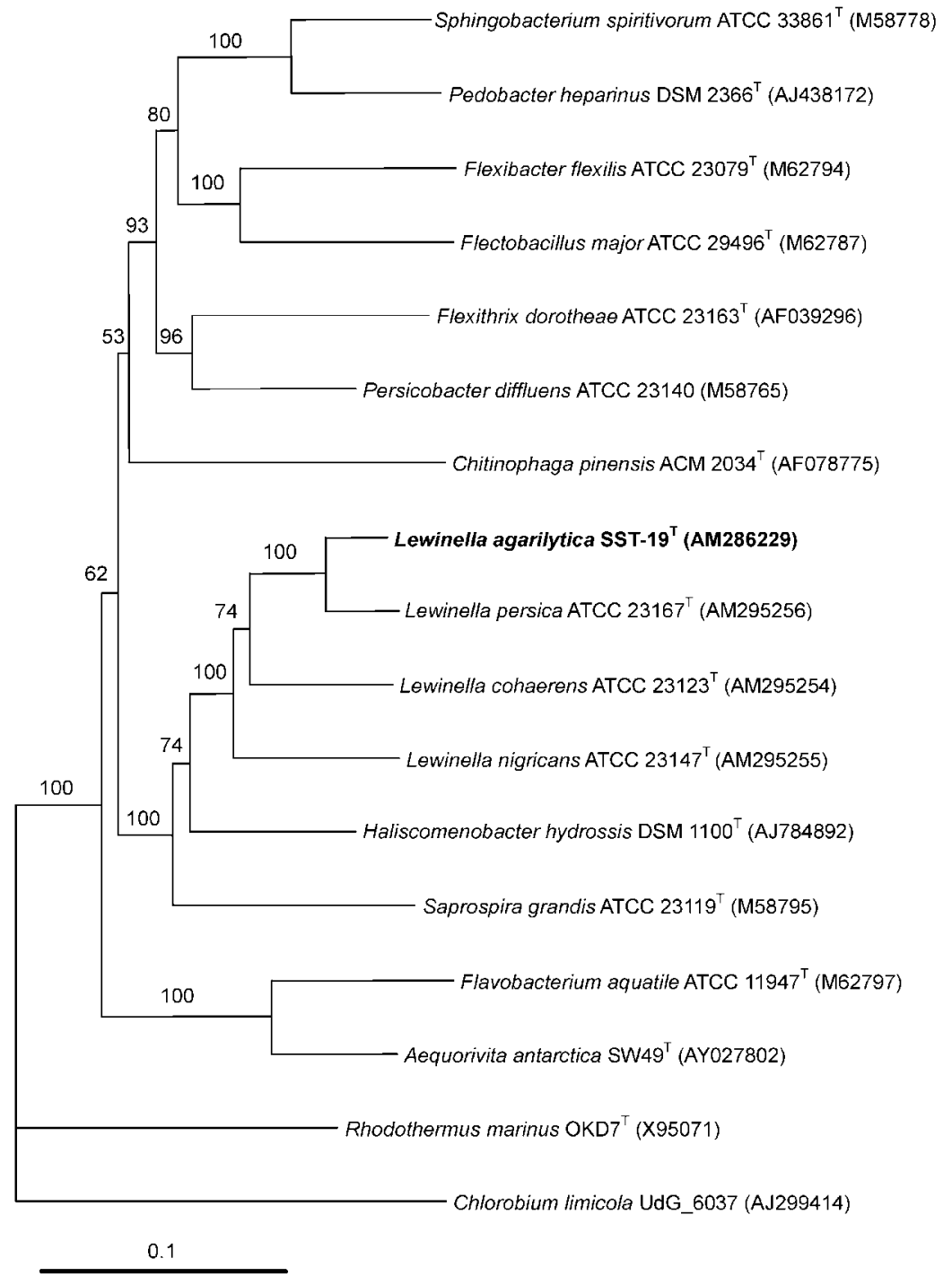

Fig. 1. Neighbour-joining phylogenetic tree, based on 16S rRNA gene sequence analysis (Saitou \& Nei, 1987), showing the position of strain SST $-19^{\top}$ within the radiation of the class Sphingobacteria. Chlorobium limicola UdG_6037 (AJ299414) was used as the outgroup. Numbers at branches indicate bootstrap percentages (based on 1000 replicates). Bar, 0.1 substitutions per nucleotide position. 
persica ATCC $23167^{\mathrm{T}}$ (94.7\% sequence similarity), with bootstrap support of $100 \%$. The levels of sequence similarity between the isolate and $L$. cohaerens ATCC $23123^{\mathrm{T}}$, L. nigricans ATCC $23147^{\mathrm{T}}$, Haliscomenobacter hydrossis DSM $1100^{\mathrm{T}}$ and Saprospira grandis ATCC $23119^{\mathrm{T}}$ were $89.0,88.4,86.4$ and $84.1 \%$, respectively. On the other hand, the organism showed sequence similarity values of only $77.5-82.0 \%$ with respect to other representatives of the class Sphingobacteria.

A cellular fatty acid analysis of strain SST $-19^{\mathrm{T}}$ and the type strains of the three recognized species of the genus Lewinella was carried out, using cells grown on MA for 7 days at $30{ }^{\circ} \mathrm{C}$. Fatty acid methyl esters were extracted and analysed according to the instructions of the Sherlock Microbial Identification System (version 6; MIDI). The $\mathrm{G}+\mathrm{C}$ content of the DNA was determined by HPLC as described by Mesbah et al. (1989).

The cellular fatty acid profile of strain SST $-19^{\mathrm{T}}$ consisted mainly of saturated, unsaturated and branched fatty acids. Small amounts of hydroxy and 10-methyl fatty acids were also detected. The predominant fatty acids were summed feature $4\left(\mathrm{C}_{16: 1} \omega 7 c\right.$ and/or iso- $\left.\mathrm{C}_{15: 0} 2-\mathrm{OH} ; 24.1 \%\right), \mathrm{C}_{18: 0}$ $(13.5 \%)$, iso- $\mathrm{C}_{15: 0}(11.1 \%)$ and $\mathrm{C}_{16: 0}(10.9 \%)$. The cellular fatty acid compositions of strain SST- $19^{\mathrm{T}}$ and the type strains of the three recognized species of the genus Lewinella are shown in Supplementary Table S1 (available in IJSEM Online). With regard to the fatty acid compositions, considerable heterogeneity was found between the members of the genus Lewinella: L. cohaerens ATCC $23123^{\mathrm{T}}$ and $L$. nigricans ATCC $23147^{\mathrm{T}}$ contain iso- $\mathrm{C}_{15: 0}$, iso- $\mathrm{C}_{15: 1}$ $\mathrm{F}, \mathrm{C}_{18: 0}$ and $\mathrm{C}_{16: 0}$ as major components, whereas L. persica ATCC $23167^{\mathrm{T}}$, like strain SST-19 ${ }^{\mathrm{T}}$, contains summed feature $4 \quad\left(\mathrm{C}_{16: 1} \omega 7 c\right.$ and/or iso- $\left.\mathrm{C}_{15: 0} \quad 2-\mathrm{OH}\right)$ as an additional major constituent and has a relatively small amount of iso- $\mathrm{C}_{15: 1} \mathrm{~F}$ in comparison with the former group. The DNA G + C content of strain SST $-19^{\mathrm{T}}$ was found to be $51.3 \mathrm{~mol} \%$.

The morphology of strain SST $-19^{\mathrm{T}}$ was examined with a transmission electron microscope using cells grown for 3 days on MA at $30{ }^{\circ} \mathrm{C}$. Gliding motility was investigated using the hanging drop method with cells grown in $0.1 \times$ marine broth (Difco) for $24 \mathrm{~h}$ at $30{ }^{\circ} \mathrm{C}$ (Bernardet et al., 2002). Colony pigmentation was checked visually and recorded after 7 days incubation at $30{ }^{\circ} \mathrm{C}$ on MA. The requirement for seawater or artificial sea salts (Sigma) for growth was investigated by using the procedure and media reported previously (Lee, 2007). Strain SST $-19^{\mathrm{T}}$ showed growth on yeast extract-malt extract agar (Shirling \& Gottlieb, 1966) and nutrient agar (Difco) supplemented with natural seawater, but not with artificial sea salts. The cells were unbranched, sheathed, flexible rods or filaments $(0.4-0.6 \times 1.5-5.0 \mu \mathrm{m})$ that consisted of three or four cells, each of $1-2 \mu \mathrm{m}$ in length (Fig. 2). Motility by means of flagella was not observed, but cells were capable of motility by gliding. Strain SST $-19^{\mathrm{T}}$ formed colonies that were light orange in colour and smooth and convex with entire edges.

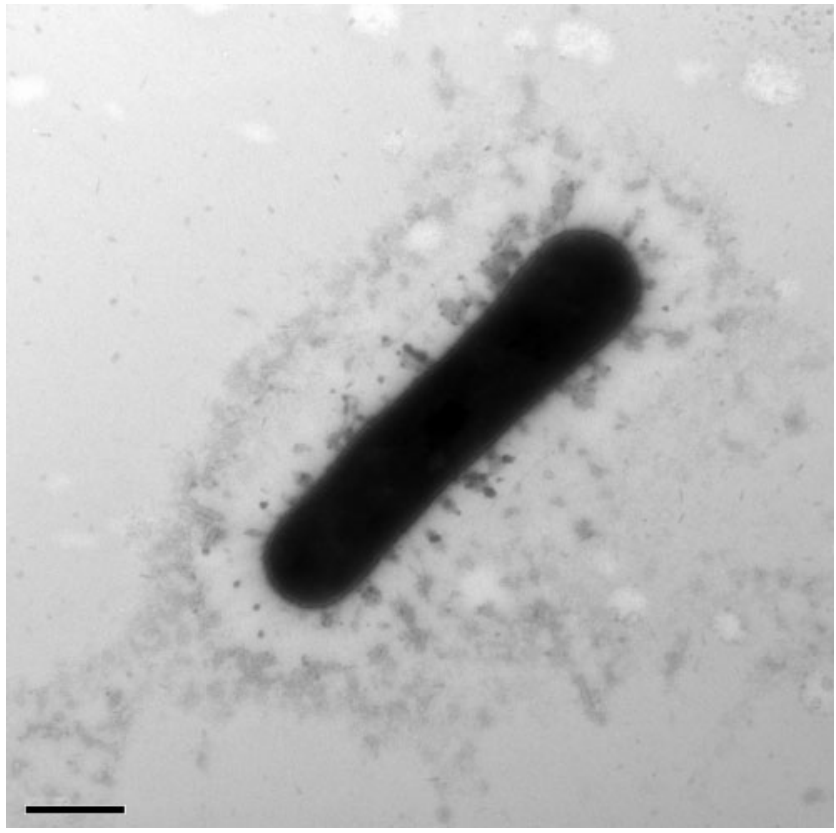

Fig. 2. Transmission electron micrograph of a cell of strain SST$19^{\top}$ grown on MA for 3 days at $30^{\circ} \mathrm{C}$. Bar, $0.5 \mu \mathrm{m}$.

The colonies reached diameters of $1-2 \mathrm{~mm}$ after 7 days incubation.

The physiological and biochemical properties of strain SST $-19^{\mathrm{T}}$ and the type strains of the three recognized species of the genus Lewinella were examined using MA as the basal medium and incubation for 7 days at $30{ }^{\circ} \mathrm{C}$, unless indicated otherwise. The results of the morphological, physiological and biochemical tests are given in Table 1 and the species description. Temperature $\left(4-42{ }^{\circ} \mathrm{C}\right)$ and initial $\mathrm{pH}(\mathrm{pH} 4.1-12.1)$ ranges for growth were determined. Tolerance of $\mathrm{NaCl}$ and artificial sea salts (Sigma) for growth were studied on $\mathrm{MA}$ using $\mathrm{NaCl}$ or sea salts at final concentrations of $1-9 \%(\mathrm{w} / \mathrm{v})$ and $0.5-7.0 \%(\mathrm{w} / \mathrm{v})$, respectively. Gram stain, catalase and oxidase activities and the degradation of casein, starch and DL-tyrosine were tested as described previously (Lee, 2006c). Hydrolysis of cellulose and chitin was tested on MA supplemented with $0.5 \%$ CM-cellulose or $0.5 \%$ colloidal chitin. Additional degradation tests involving hypoxanthine and xanthine were performed using $\mathrm{MA}$ as the basal medium, as described by Gordon et al. (1974). The results from the degradation tests were recorded after incubation for 14 days at $30{ }^{\circ} \mathrm{C}$. Tests for other physiological and biochemical characteristics were performed using API 20NE and API ZYM strips (bioMérieux) according to the manufacturer's instructions, but the results for assimilation tests in the API 20NE strips were recorded after incubation for 5 days at $30{ }^{\circ} \mathrm{C}$. The cells were grown on MA for 2 days at $30{ }^{\circ} \mathrm{C}$ and suspended in a solution of $1 \%(\mathrm{w} / \mathrm{v})$ sea salts before inoculation. Characteristics that serve to differentiate between strain SST $-19^{\mathrm{T}}$ and the type strains of 
Table 1. Differential characteristics of strain SST-19 ${ }^{\top}$ (Lewinella agarilytica sp. nov.) and the type strains of recognized species of the genus Lewinella

Strains: 1, SST-19 ${ }^{\mathrm{T}}$; 2, L. cohaerens ATCC $23123^{\mathrm{T}} ; 3$, L. nigricans ATCC $23147^{\mathrm{T}} ; 4$, L. persica ATCC $23167^{\mathrm{T}}$. Data were taken from Lewin $(1970)$, Holt (1989) and this study. All were positive or weakly positive for alkaline phosphatase, esterase (C4), leucine arylamidase, valine arylamidase, cystine arylamidase, acid phosphatase and $N$-acetyl- $\beta$-glucosamidase, but negative for lipase (C14), $\alpha$-chymotrypsin, $\alpha$-galactosidase, $\beta$ glucuronidase, $\alpha$-mannosidase and $\alpha$-fucosidase (API ZYM). With the API $20 \mathrm{NE}$ strip, aesculin degradation, gelatin hydrolysis and $\beta$-galactosidase gave positive results for all strains, but nitrate reduction, indole production, glucose fermentation, arginine dihydrolase and urease were negative for all strains. All assimilated D-glucose, D-mannose, $\mathrm{N}$-acetyl-D-glucosamine and maltose, but not D-arabinose, D-mannitol, gluconate, caprate or phenylacetate. All showed growth at an initial $\mathrm{pH}$ of $7.1-8.1$ and a temperature of $25-30{ }^{\circ} \mathrm{C}$, and tolerated $1 \% \mathrm{NaCl}$ on $\mathrm{MA}$. Degradation of cellulose, chitin, hypoxanthine and xanthine was not observed in any of the strains. All required seawater for growth. +, Positive; - , negative; w, weak.

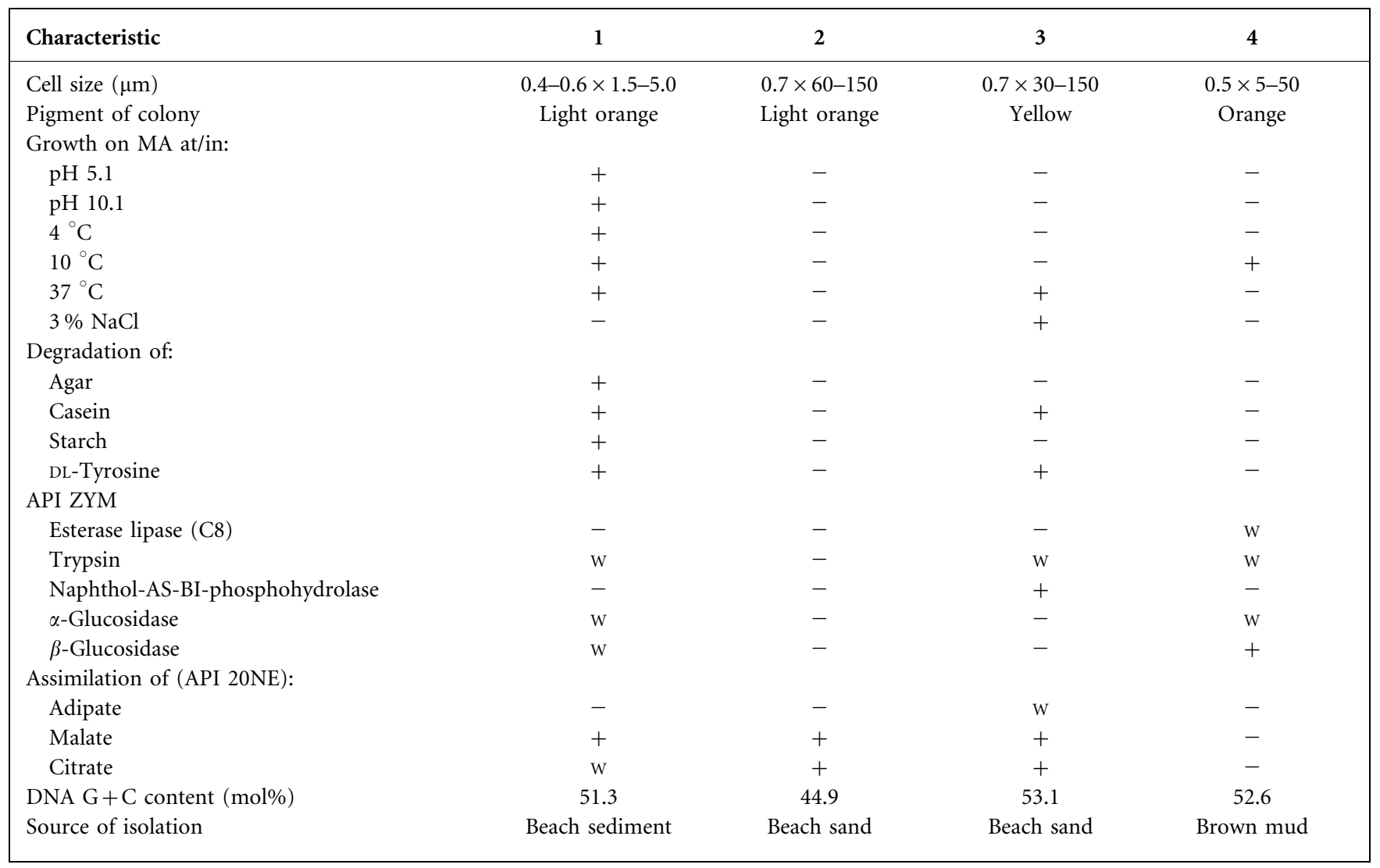

recognized species of the genus Lewinella are given in Table 1.

On the basis of the phenotypic and molecular genetic data presented here, strain SST $-19^{\mathrm{T}}$ represents a novel species of the genus Lewinella, for which the name Lewinella agarilytica sp. nov. is proposed.

\section{Description of Lewinella agarilytica sp. nov.}

Lewinella agarilytica (a.ga.ri.ly'ti.ca. Malayan n. agar agar, gelling polysaccharides from seaweed; N.L. n. agarum agar; N.L. adj. lyticus - a-um from Gr. adj. lutikos dissolving; N.L. fem. adj. agarilytica agar-dissolving).

Aerobic, Gram-negative, catalase-positive, oxidase-positive and heterotrophic. Cells are unbranched, sheathed, flexible rods or filaments $(0.4-0.6 \times 1.5-5.0 \mu \mathrm{m})$ that contain $3-4$ individual cells that are each $1-2 \mu \mathrm{m}$ in length. Long filaments $(10-150 \mu \mathrm{m})$ are not observed. Gliding motility is observed. Colonies are opaque, convex, circular and light orange in colour. Temperature range for growth is 4$37{ }^{\circ} \mathrm{C}$, with optimum growth at $30{ }^{\circ} \mathrm{C}$. No growth is observed at $42{ }^{\circ} \mathrm{C}$. Growth occurs at $\mathrm{pH}$ 5.1-10.1, with optimum growth occurring under alkaline conditions (pH 8.1-9.1). Seawater is required for growth. Growth occurs on MA containing $1 \% \mathrm{NaCl}$ or $0.5-1 \%$ artificial sea salts. Agar, casein and starch are hydrolysed. DL-Tyrosine is decomposed. Positive or weakly positive for assimilation of malate and citrate. Adipate is not assimilated. In API ZYM tests, trypsin, $\alpha$-glucosidase and $\beta$-glucosidase activities are weakly positive. Negative for esterase lipase (C8) and naphthol-AS-BI-phosphohydrolase activities. Major cellular fatty acids are $\mathrm{C}_{16: 1} \omega 7 c$ and/or iso- $\mathrm{C}_{15: 0} 2-\mathrm{OH}$ $(24.1 \%), \mathrm{C}_{18: 0}(13.5 \%)$, iso- $\mathrm{C}_{15: 0}(11.1 \%)$ and $\mathrm{C}_{16: 0}$ 
(10.9\%). The DNA G+C content of the type strain is $51.3 \mathrm{~mol} \%$.

The type strain, SST- $19^{\mathrm{T}} \quad\left(=\mathrm{JBRI} \quad 2009^{\mathrm{T}}=\mathrm{KCTC}\right.$ $12774^{\mathrm{T}}=\mathrm{JCM} 14216^{\mathrm{T}}$ ), was isolated from beach sediment on the coast of Jeju Island, Republic of Korea.

\section{Acknowledgements}

This work was supported by the 21C Frontier Microbial Genomics and Application Center Program, Ministry of Science and Technology, Republic of Korea. The author is grateful to Hong Lim Yang for her technical assistance.

\section{References}

Bernardet, J.-F., Nakagawa, Y. \& Holmes, B. (2002). Proposed minimal standards for describing new taxa of the family Flavobacteriaceae and emended description of the family. Int J Syst Evol Microbiol 52, 1049-1070.

Brosius, J., Palmer, J. L., Kennedy, J. P. \& Noller, H. F. (1978). Complete nucleotide sequence of a $16 \mathrm{~S}$ ribosomal RNA gene from Escherichia coli. Proc Natl Acad Sci U S A 75, 4801-4805.

Felsenstein, J. (1985). Confidence limits on phylogenies: an approach using the bootstrap. Evolution 39, 783-791.

Garrity, G. M. \& Holt, J. G. (2001). Phylum BVI. Chloroflexi phy. nov. In Bergey's Manual of Systematic Bacteriology, 2nd edn, vol. 1 (The Archaea and the deeply branching and phototrophic Bacteria), pp. 427-446. Edited by D. R. Boone, R. W. Castenholz \& G. M. Garrity. New York: Springer.

Gordon, R. E., Barnett, D. A., Handerhan, J. E. \& Pang, C. H.-N. (1974). Nocardia coeliaca, Nocardia autotrophica, and the nocardin strain. Int J Syst Bacteriol 24, 54-63.

Gross, J. (1911). Über freilebende Spironemaceen. Mitt Zool Stat Neapel 20, 188-203.

Holt, J. G. (1989). Genus Herpetosiphon Holt and Lewin, 1965, $2408^{\mathrm{AL}}$. In Bergey's Manual of Systematic Bacteriology, vol. 3, pp. 2136-2138. Edited by J. T. Staley, M. P. Bryant, N. Pfennig \& J. G. Holt. Baltimore: Williams \& Wilkins.
Holt, J. G. \& Lewin, R. A. (1968). Herpetosiphon aurantiacus gen. et sp. n., a new filamentous gliding organism. J Bacteriol 95, 2407-2408.

Jukes, T. H. \& Cantor, C. R. (1969). Evolution of protein molecules. In Mammalian Protein Metabolism, vol. 3, pp. 21-132. Edited by H. N. Munro. New York: Academic Press.

Lee, S. D. (2006a). Blastococcus jejuensis sp. nov., an actinomycete from beach sediment, and emended description of the genus Blastococcus Ahrens and Moll 1970. Int J Syst Evol Microbiol 56, 2391-2396.

Lee, S. D. (2006b). Brevibacterium samyangense sp. nov., an actinomycete isolated from a beach sediment. Int J Syst Evol Microbiol 56, 1889-1892.

Lee, S. D. (2006c). Kineococcus marinus sp. nov., isolated from marine sediment of the coast of Jeju, Korea. Int J Syst Evol Microbiol 56, 1279-1283.

Lee, S. D. (2007). Tamnana crocina gen. nov., sp. nov., a marine bacterium of the family Flavobacteriaceae, isolated from beach sediment in Korea. Int J Syst Evol Microbiol 57, 764-769.

Lewin, R. A. (1970). New Herpetosiphon species (Flexibacterales). Can J Microbiol 16, 517-520.

Mesbah, M., Premachandran, U. \& Whitman, W. B. (1989). Precise measurement of the $\mathrm{G}+\mathrm{C}$ content of deoxyribonucleic acid by highperformance liquid chromatography. Int J Syst Bacteriol 39, 159-167.

Saitou, N. \& Nei, M. (1987). The neighbor-joining method: a new method for reconstructing phylogenetic trees. Mol Biol Evol 4, 406-425.

Shirling, E. B. \& Gottlieb, D. (1966). Methods for characterization of Streptomyces species. Int J Syst Bacteriol 16, 313-340.

Sly, L. I., Taghavi, M. \& Fegan, M. (1998). Phylogenetic heterogeneity within the genus Herpetosiphon: transfer of the marine species Herpetosiphon cohaerans, Herpetosiphon nigricans and Herpetosiphon persicus to the genus Lewinella gen. nov. in the FlexibacterBacteroides-Cytophaga phylum. Int J Syst Bacteriol 48, 731-737.

Thompson, J. D., Gibson, T. J., Plewniak, F., Jeanmougin, F. \& Higgins, D. G. (1997). The CLUSTAL_X windows interface: flexible strategies for multiple sequence alignment aided by quality analysis tools. Nucleic Acids Res 25, 4876-4882.

van Veen, W. L., van der Kooij, D., Geuze, E. C. W. A. \& van der Vlies, A. W. (1973). Investigations on the sheathed bacterium Haliscomenobacter hydrossis gen. n., sp. n., isolated from activated sludge. Antonie Van Leeuwenhoek 39, 207-216. 